\title{
LA ARQUITECTURA COLONIAL A TRAVÉS DE LAS PORTADAS DE LOS EDIFICIOS CIVILES
}

\author{
Manuel González GalváN
}

Así como el rostro no es el cuerpo, la fachada no es un edificio, pero, así como también la fisonomía y el carácter de una persona se sintetizan en su cara, a través de las fachadas y, precisando, de las portadas civiles, puede rastrearse la intención social y la evolución estilística que marcó la arquitectura de la época virreinal.

La arquitectura religiosa fue la más rica y esplendente, como refugio y clamor que fue de los gustos, problemas y anhelos propios de la sociedad que la erigió, y por su abundancia y pertenecer al patrimonio común, se ha preservado más que lo que ha podido soportar la arquitectura civil, sujeta al capricho individualista de los propietarios particulares.

De la riqueza y variedad de las portadas religiosas se ha ocupado y ha hecho un cumplido y amplio estudio la doctora Elisa Vargas Lugo.*

Aquí, a continuación, consideramos que estas líneas apenas son como un apunte con respecto a las portadas de carácter civil, ya que si el templo manifiesta la fe, el palacio exalta a la autoridad o el apellido, y a su vez, aun la mínima casa lo hace con la costumbre familiar.

La sociedad colonial, organizada sobre cimientos teocráticos, era natural que rindiera tributo a todo lo que significa honor y religión, pues nobleza de sangre y virtud espiritual eran timbres de gloria terrenal y celestial que se enfatizaban como supremos anhelos vitales. De esta actitud surge la recíproca presencia de escudos nobiliarios y nichos con imágenes y símbolos religiosos, de tiaras y coronas, de historiadas inscripciones de alabanzas, salutaciones y anagramas que, como una constante, pueblan las portadas civiles.

Todo ello hace el "mensaje" social de la portada, la razón de su derroche plástico y, en última instancia, sui independencia de lo puramente utilitario, de manera que, aunque bárbaramente se las arranque o anule del conjunto, conservan voz propia y sugieren y hacen lamentar lo perdido, pues son lo que el prólogo al libro.

* Las portadas religiosas de México. México, Instituto de Investigaciones Estéticas, UNAM (Estudios y Fuentes del Arte en México, XXVII), primera edición: 1969, segunda edición: 1986. 
La portada civil es plasmación de un concepto de anfitrión. Es elocuente testimonio externo de la vida que fluye tras ella en los espacios internos, regidos por los diques y compuertas que la planta ordena en muros, espacios y circulaciones.

La portada es a la arquitectura civil lo que el retablo a la eclesiástica; estructura simbólica, independiente en sí, pero complementaria del conjunto. Da lustre y luce como joya engarzada en la fachada. Su belleza es anzuelo que sujeta la atención y, con ello, cumple su principal función, que es de orden más sicológico que utilitario.

Al desplegarse y crecer, ennoblece ejes de composición y dignifica el paso del hombre, su grandeza engrandece la escala humana. Las grandes portadas no quieren ser sólo agujeros de paso, sino exaltación del acceso; aduanas de la emoción.

Así, los estilos, que son una forma de sentir y apreciar la vida, fueron dejando en ellas su firma de identificación estética y cronológica, al grado de poder seguir, sólo en ellas, la historia formal del arte colonial, aunque a grandes saltos, con ejemplos muy significativos.

Del plateresco civil, conservamos casi exclusivamente portadas; en Puebla, "La Casa del que Mató al Animal" (fig. 1) en donde las anchas jambas y dintel permiten el desarrollo, en relieve bajo y plano, de una muy medieval escena de cacería, al parecer escapada de un tapiz; quedan, también en Puebla, un fragmento de la antigua alhóndiga, con roleos quiméricos, en donde lo vegeial y humano se combinan para animar lo abstracto del esquema arquitectónico, y la portada de la "Casa de los Bustos" (fig. 2), donde al contrastar en altorrelieve los bustos de un joven y un viejo, se incita a meditar sobre el tiempo. En Cholula, una casa que frente a la plaza y entre el convento y la parroquia ostenta, uniendo el dintel y jambas de su portada, dos preciosas zapatas de piedra que alojan un par de caballeros águila, como prueba de ese matiz prehispánico que penetró en lo virreinal, sobreviviendo en tono menor.

En Tlaxcala, también algunos elementos mudéjares y góticos se aclimatan al golpe del cincel indígena en la portada del Palacio de Gobierno (fig. 3) y, sobre todo, en la preciosa doble arquería que se abre a la plaza, con ese sentido de arquitectura abierta al servicio público, tan peculiar de los ayuntamientos castellanos; otro tanto sucede en edificios similares, como son los palacios municipales de Metztitlán y Atotonilco.

De sentido heráldico hay, en San Cristóbal las Casas, un bello ejemplo de argamasa en la llamada "Casa de Mazariegos" (fig. 4), con esa mezcla de sencillez y grandeza propios de la hidalguía; finalmente, la casa 
de "Montejo" en Mérida (fig. 5) ostenta, sin duda, la más monumental, pura y rica portada del plateresco civil en todo el país.

Del Renacimiento más depurado se conserva, aunque maltrecha, una casa, también en Mérida, con marcada influencia Vitrubiana y, en Puebla, la elegante "Casa del Deán", de tipo manierista.

Con los siglos XVII y XVIII y la presencia del barroco y sus modalidades, la lista de ejemplos se alarga y enriquece, a la vez que las ciudades van creando detalles locales en el tratamiento de algunos elementos.

La ciudad de México suaviza su primigenio aire militar y los torreones de las esquinas se convierten en miradores (fig. 6), los cañones truecan su estallido por el canto del agua al caer, convirtiéndose en gárgolas y las almenas devienen en airosos y floridos remates, la guerra se vuelve juego en el recuerdo. Tal acontece en palacios como los de Torre Cossío, Calimaya, San Mateo Valparaíso y Jaral de Berrio.

En la misma ciudad, el vano de ingreso adquiere tanta monumental dignidad que en muchos casos su altura ocupa la de dos plantas, como en el propio Palacio de los Virreyes, la Aduana de Santo Domingo y numerosos edificios particulares.

Otras ciudades, según sus circunstancias de geografía, clima y materiales, van aportando rasgos peculiares. Oaxaca, a la inversa de México, en muchas portadas simula dos cuerpos, aunque el edificio sea de una sola planta, retando con esta gallardía artística el sísmico subsuelo en que se levanta (fig. 7). Guadalajara suaviza los ángulos urbanos poniendo en las esquinas redondas columnas inspiradas por el interior de su Catedral (fig. 8). Morelia (fig. 9) cubre los balcones con pétreos aleros que eternizan, en cantera, el cobijo de madera que lucen las ciudades de serranía próximas a ella como Pátzcuaro, Tacámbaro y Uruapan. Durango se distingue precisamente por sus portadas con airosos imafrontes que riman como acentos verticales las perspectivas urbanas y sirven de postas a la belleza en fuga (fig. 10). Y así, tantas otras poblaciones que, como Puebla, estallan en el colorido de sus azulejos aglutinados entre el rojo del barro cocido y el blanco del estuco; baste citar como ejemplos "La Casa de Alfeñique" y la "Casa de los Muñecos".

A todo se debe añadir la creciente euforia ornamental que, sin embargo, no cayó en el caos, antes bien, como enredadera sobre firme apoyo, se sujetó a la evolución seguida por la composición arquitectónica y su elemento representativo: columnas y pilastras (fig. 11).

El tipo de pilastras tableradas, el más abundante en toda la arquitectura civil, tiene ejemplos tan notables como el Palacio de Gobierno en 
Morelia (antiguo Seminario), (fig. 12) o el de Los Marqueses del Villar del Águila en Querétaro. De columnas tritóstilas, o de tercios marcados, abundan en Oaxaca, Zacatecas y San Luis Potosí. Las hay también salomónicas (fig. 13), sobre todo en la zona centro y norte del país y, desde luego, los estípites, que van de la portada del Arzobispado de México, fechada en 1743, y la "Casa de los Mascarones" (fig. 14) al esplendor de casi retablo pétreo en la Casa de los Condes de Súchil en Durango, sin faltar las últimas palabras del barroco ya "anástilo", como es el caso de la Alhóndiga en Morelia (fig. 15) para que, finalmente, al concluir los tiempos virreinales y presentarse un nuevo estilo, el neoclásico, con intenciones devastadoras, hubiese, por momentos, un cortés diálogo plástico del que dan prueba numerosas portadas, principalmente en San Miguel Allende y más específicamente en el Palacio de los Condes de la Canal (fig. 16), donde la balanza de la clasificación estilística oscila entre el barroco y el neoclásico, pues de ambos tiene.

Claro ejemplo de ese armisticio de los estilos en vísperas de la guerra de Independencia. Guerra que se abrirá, a su vez, como portada grandiosa de la sociedad naciente, poniendo en comunicación el vigor interno con la fuerza externa del mundo y la historia.

\section{CRÉDITOS FOTOGRÁFICOS}

Las figuras $1,2,5,7$ y 16, provienen de la fototeca del I.I.E.; todas las demás son fotografías del autor. 
DOI: http://dx.doi.org/10.22201/iie.18703062e.1989.60.1540

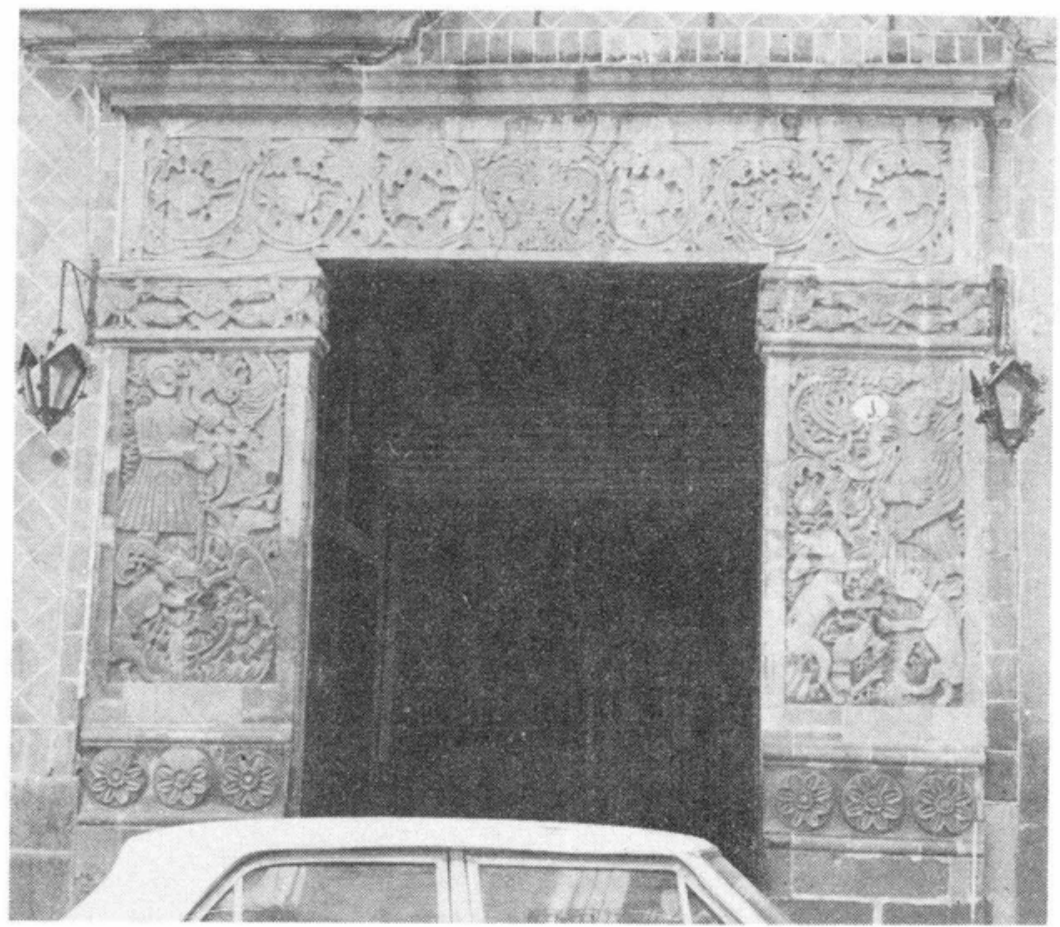

1. Puebla, Pue. "Casa del que mató al animal". Siglo XVI.

2. Puebla, Pue. "Casa de los bustos". Siglo XVI.

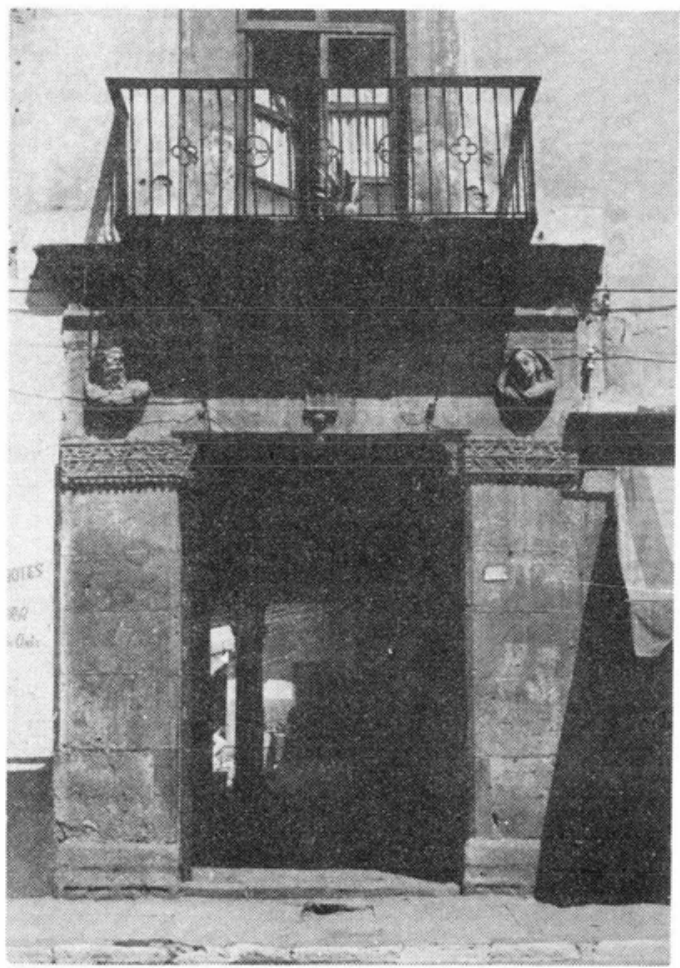


DOI: http://dx.doi.org/10.22201/iie.18703062e.1989.60.1540

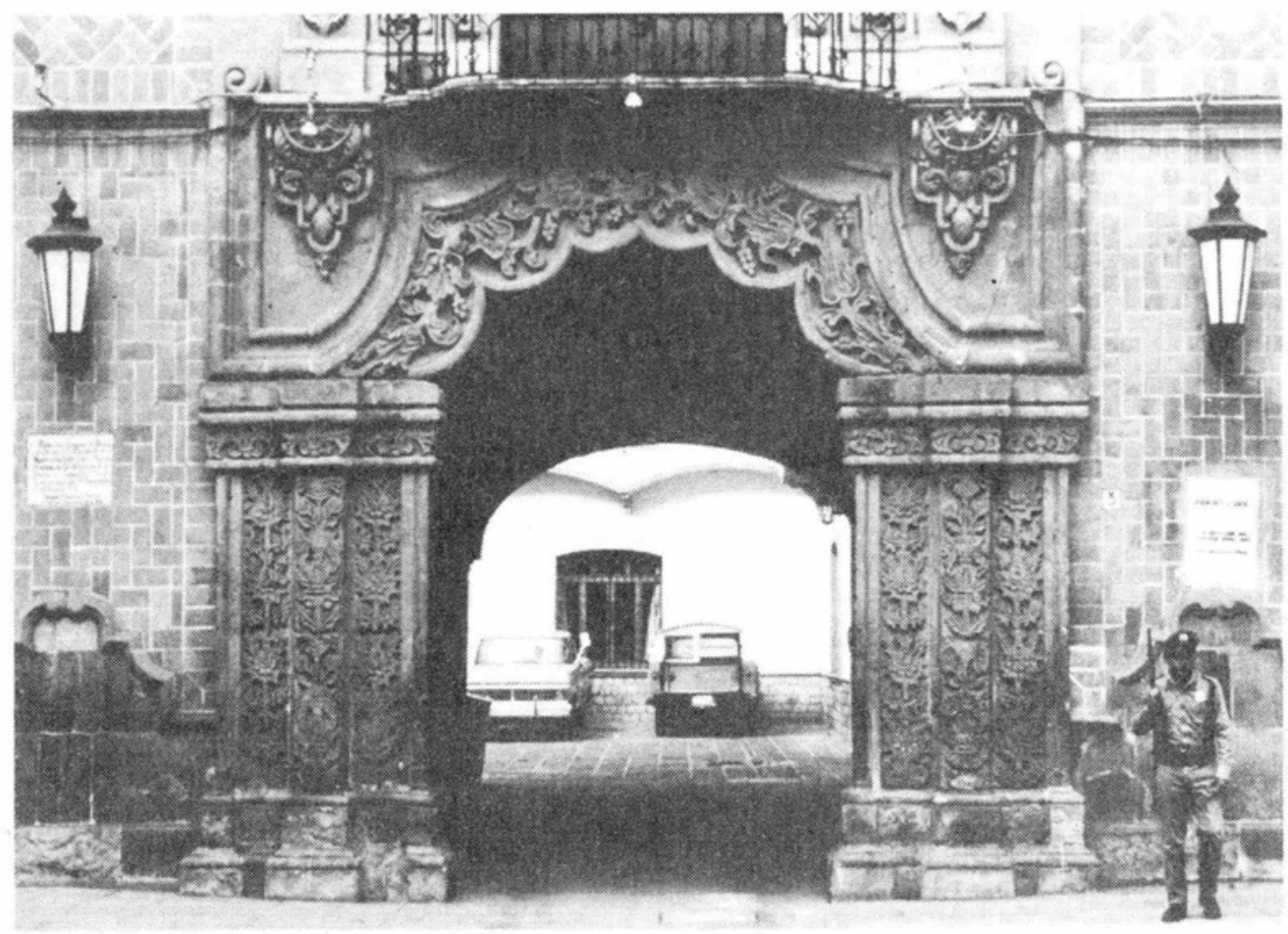

3. Tlaxcala, Tlax. Portada del Palacio de Gobierno. Siglo XVI.

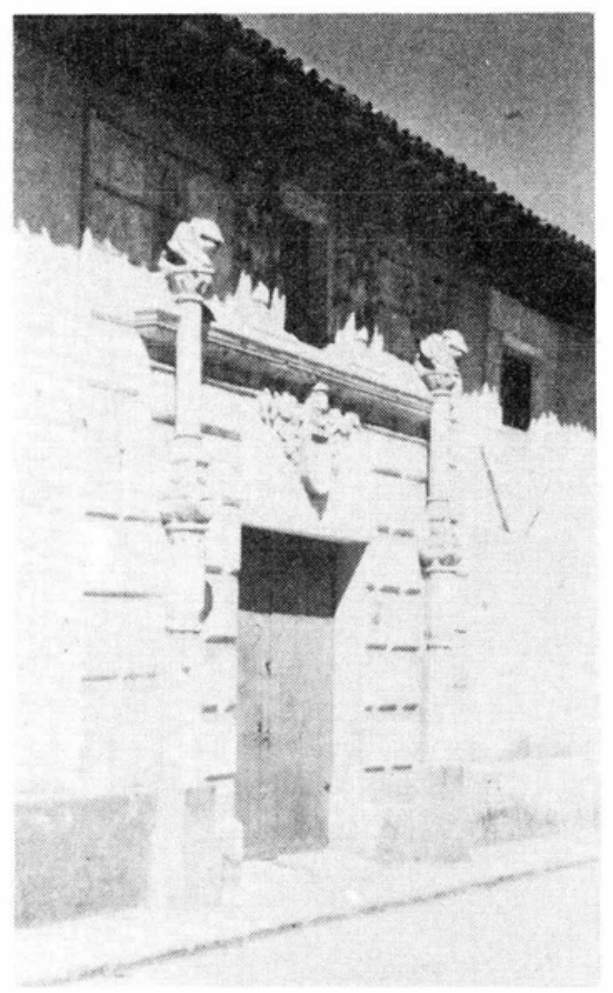

4. San Cristóbal las Casas, Chis. "Casa de Mazariegos". Siglo XVI. 
DOI: http://dx.doi.org/10.22201/iie.18703062e.1989.60.1540

5. Mérida, Yuc. "Casa de Montejo". Siglo XVI.

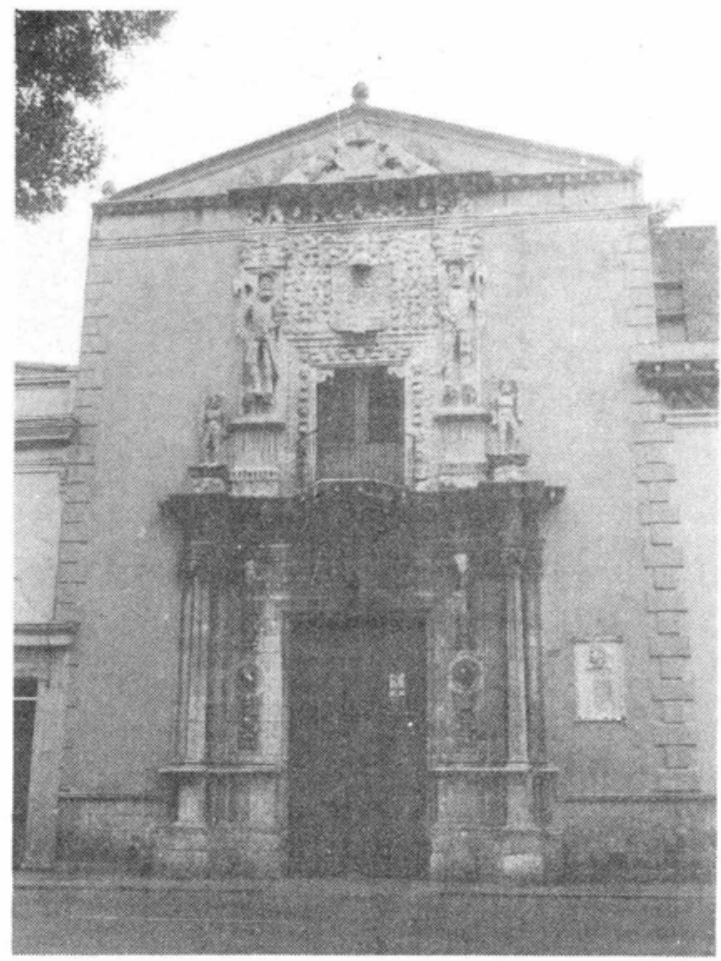

6. México, D. F. Palacio del Mayorazgo de Guerrero. Siglo XVIII.

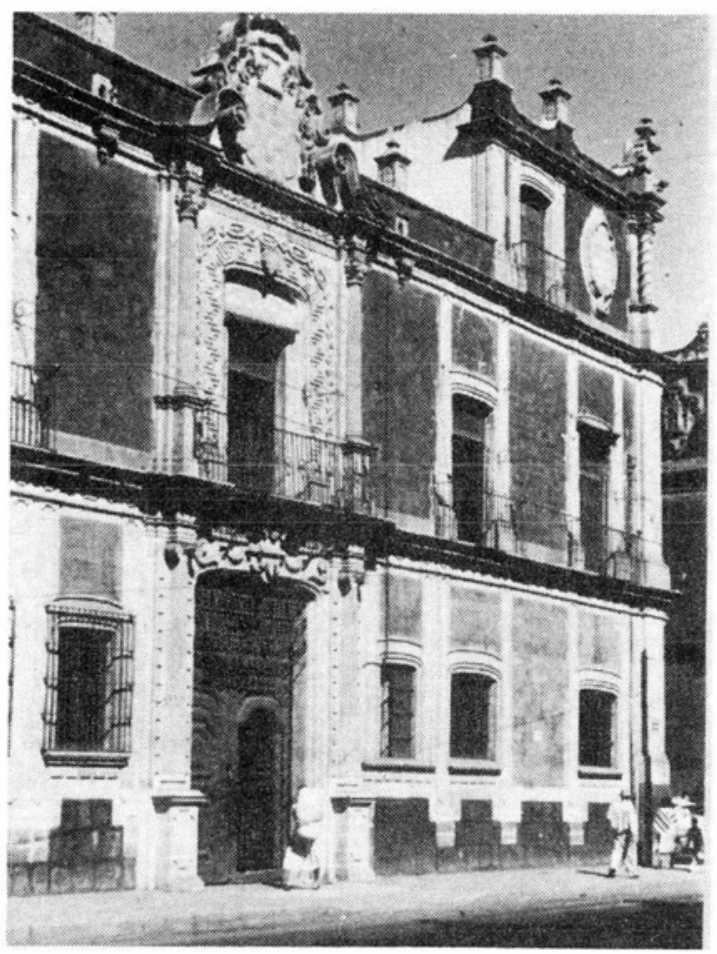


DOI: http://dx.doi.org/10.22201/iie.18703062e.1989.60.1540

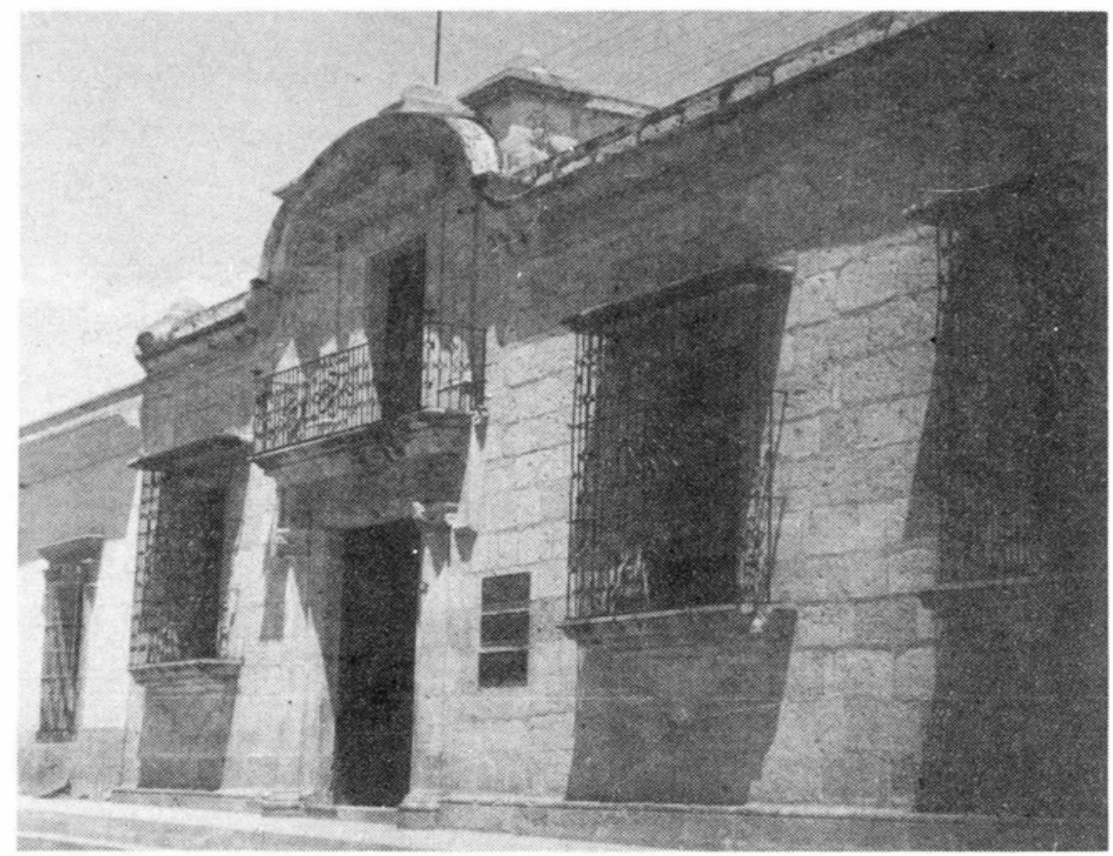

7. Oaxaca, Oax. Museo Tamayo. Casa del siglo XVIII.

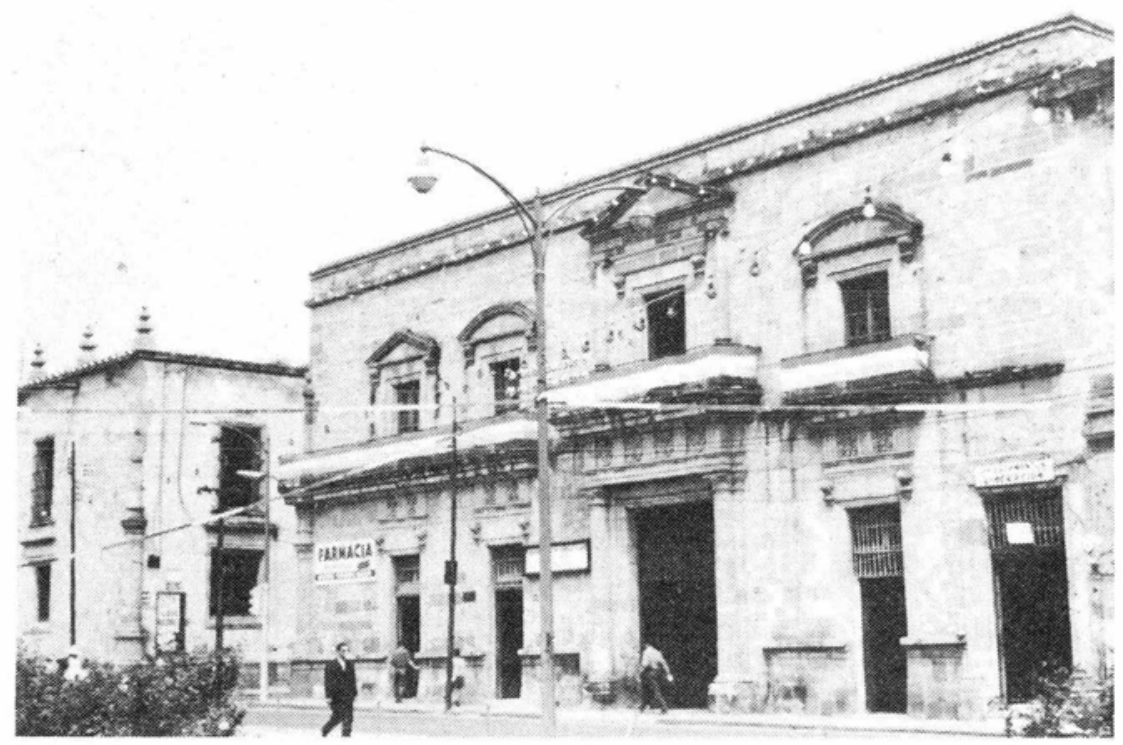

8. Guadalajara, Jal. Esquinas del antiguo Seminario, hoy Museo Regional y casa monumental. Siglos XVIII y XIX, respectivamente. 


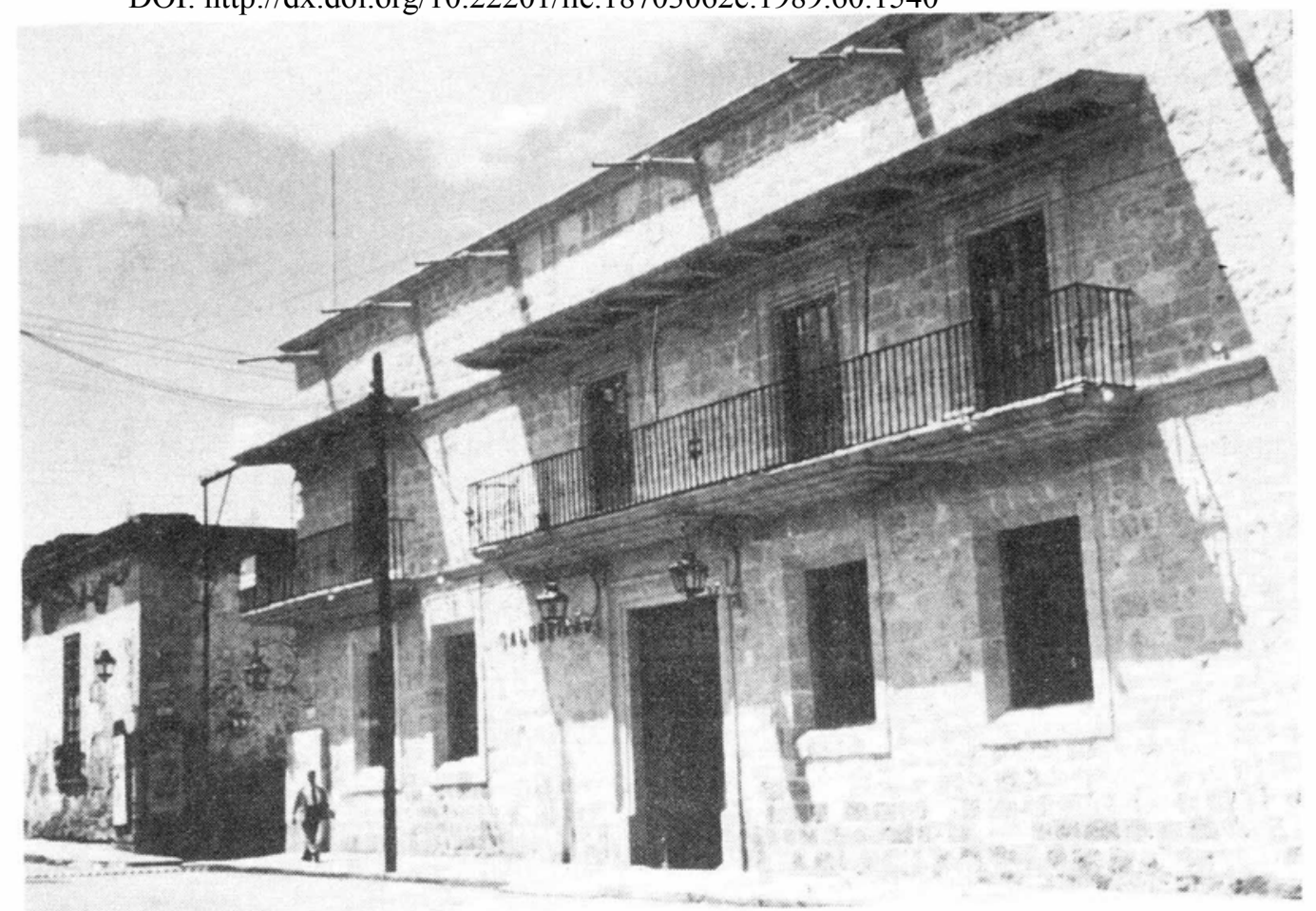

9. Morelia, Mich. Antiguo Palacio Episcopal, hoy oficinas de Salubridad Pública. Siglo XVIII.

10. Durango, Dgo. Casa del siglo XVIII.

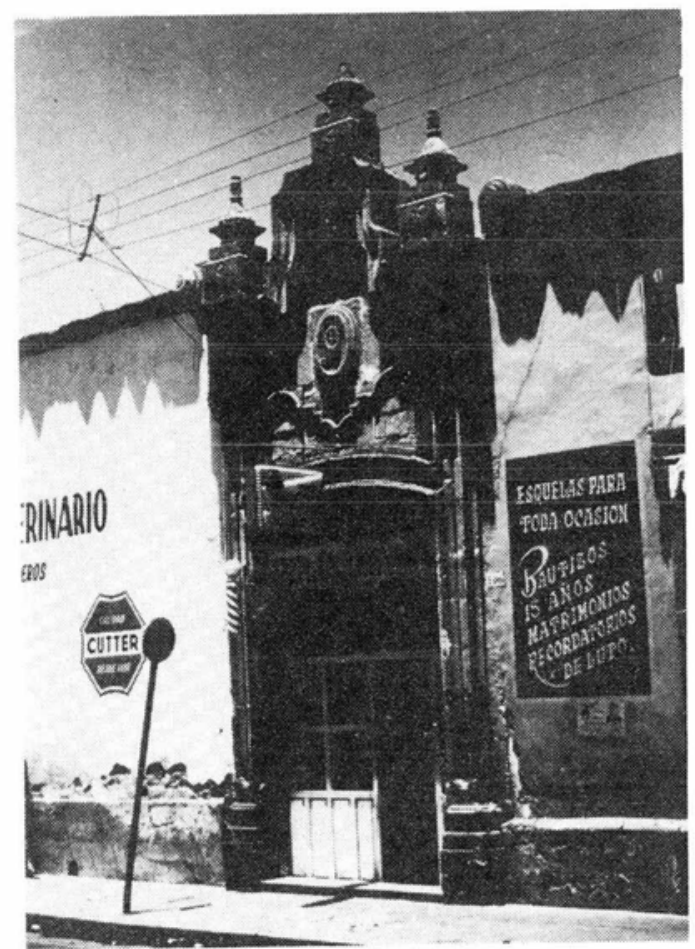


DOI: http://dx.doi.org/10.22201/iie.18703062e.1989.60.1540

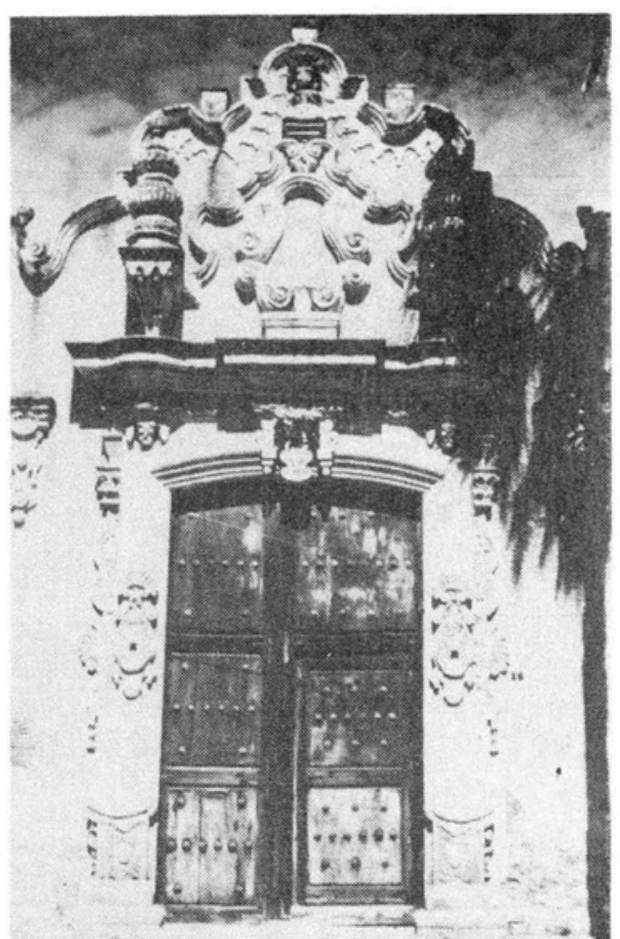

11. Apaseo el Grande, Gto. "Casa de los perros". Siglo XVIII.

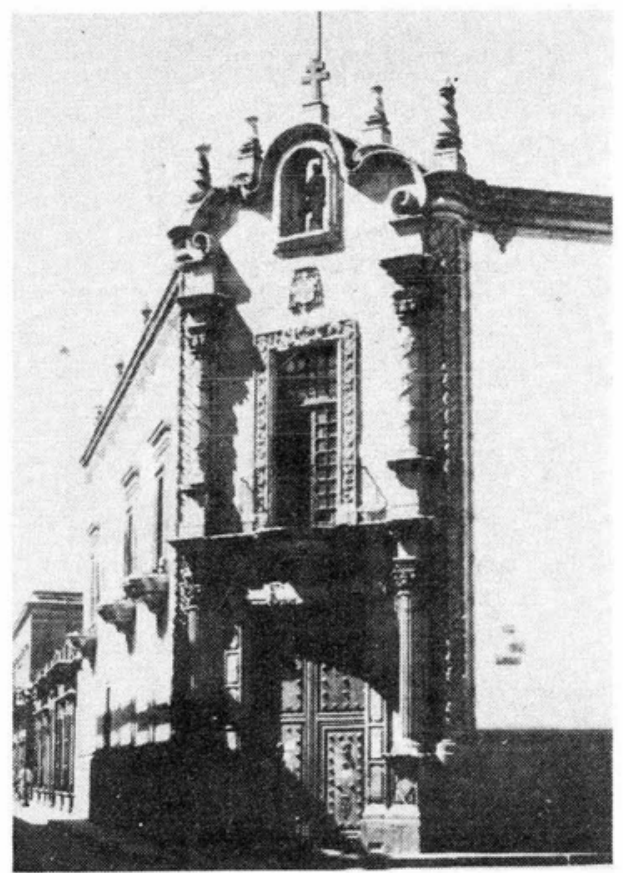

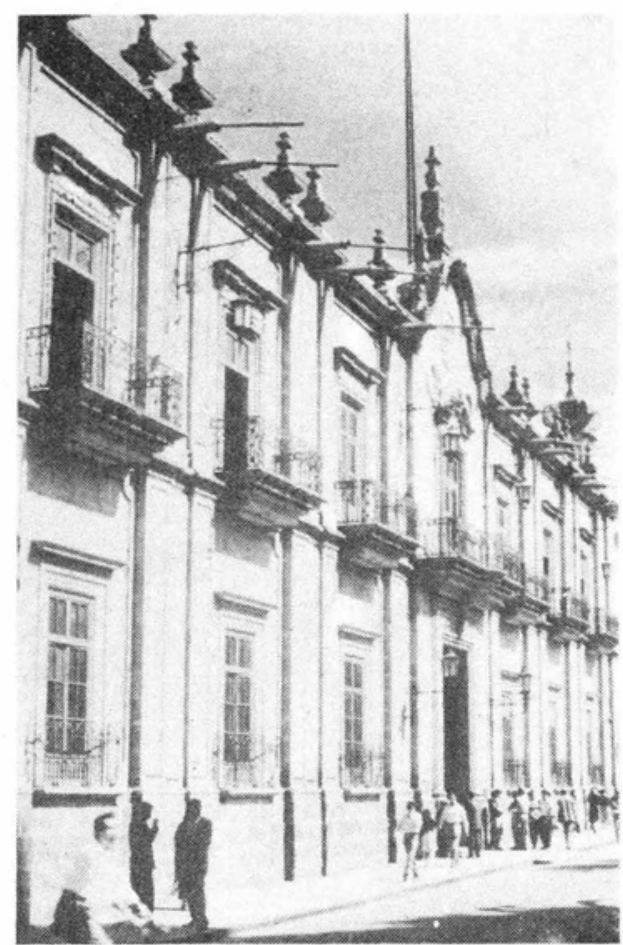

12. Morelia, Mich. Antiguo Seminario, hoy Palacio de Gobierno. Siglo XVIII.
13. San Luis Potosí, S.L.P., Antigua Casa de Moneda. Siglo XVIII. 
DOI: http://dx.doi.org/10.22201/iie.18703062e.1989.60.1540

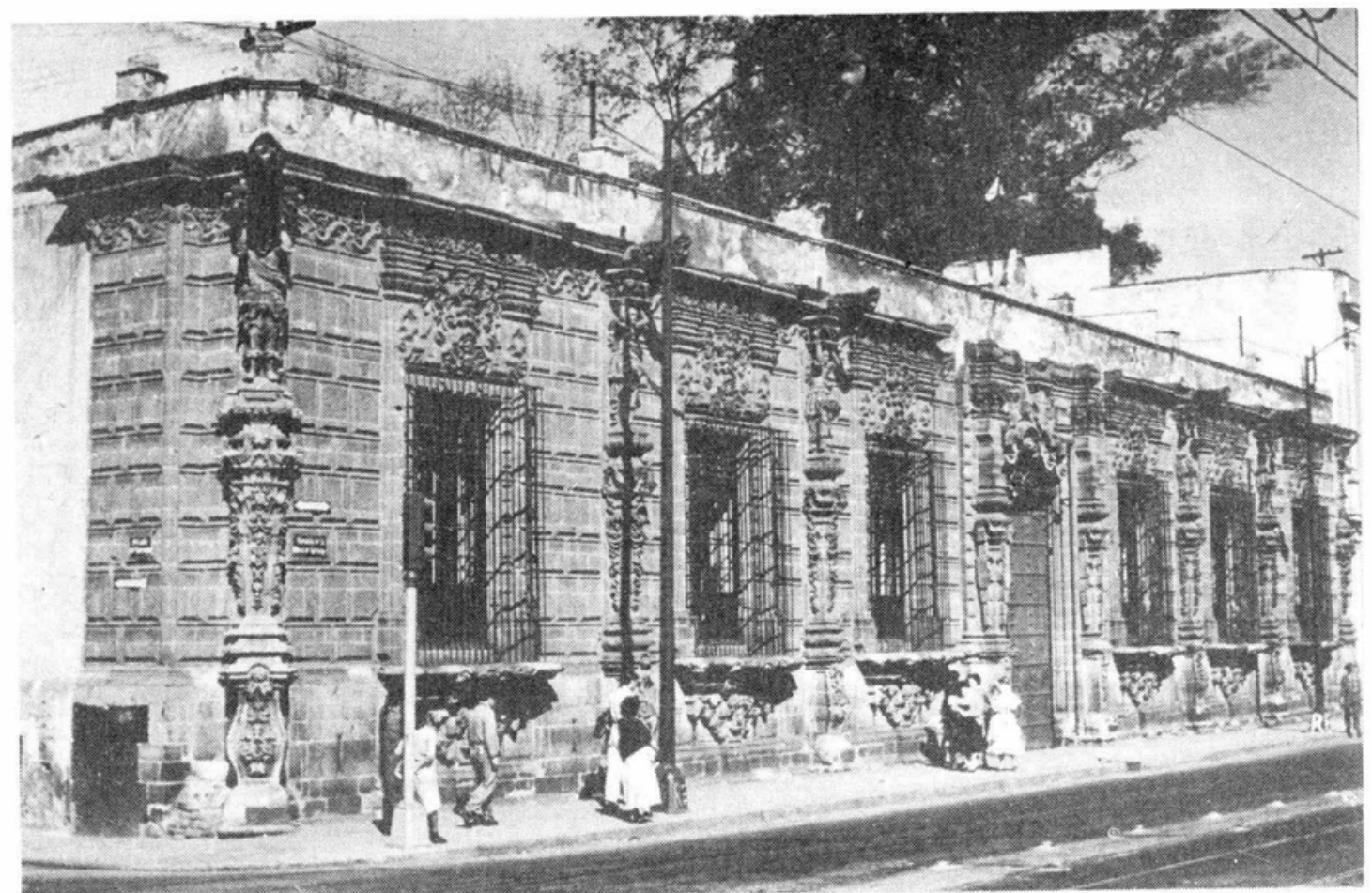

14. México, D. F. "Casa de los Mascarones”. Siglo XVIII.

15. Morelia, Mich. Antigua Alhóndiga. Siglo XVIII.

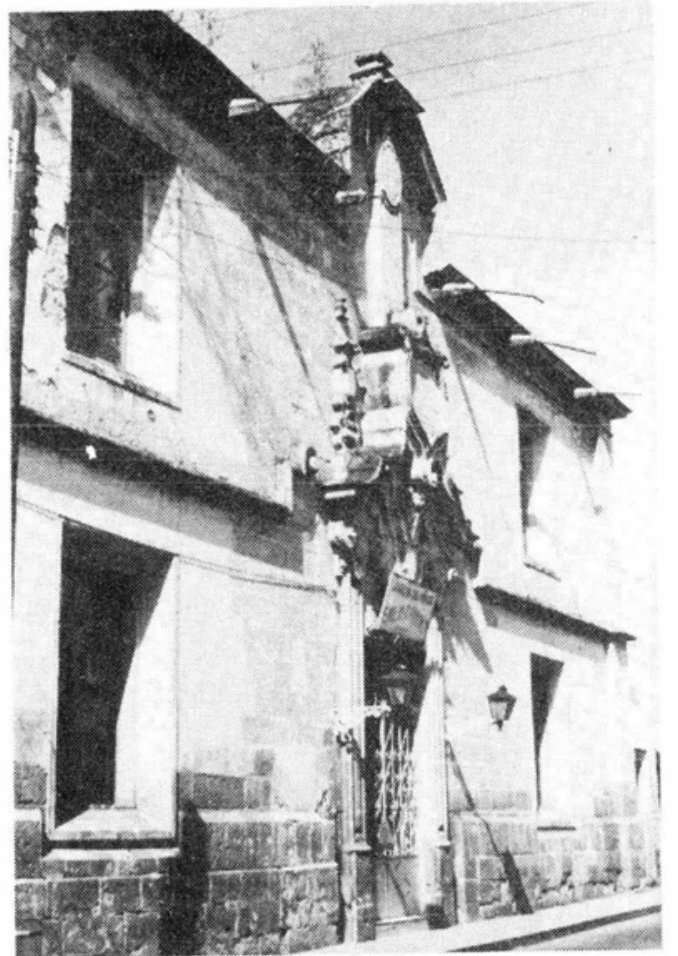


DOI: http://dx.doi.org/10.22201/iie.18703062e.1989.60.1540

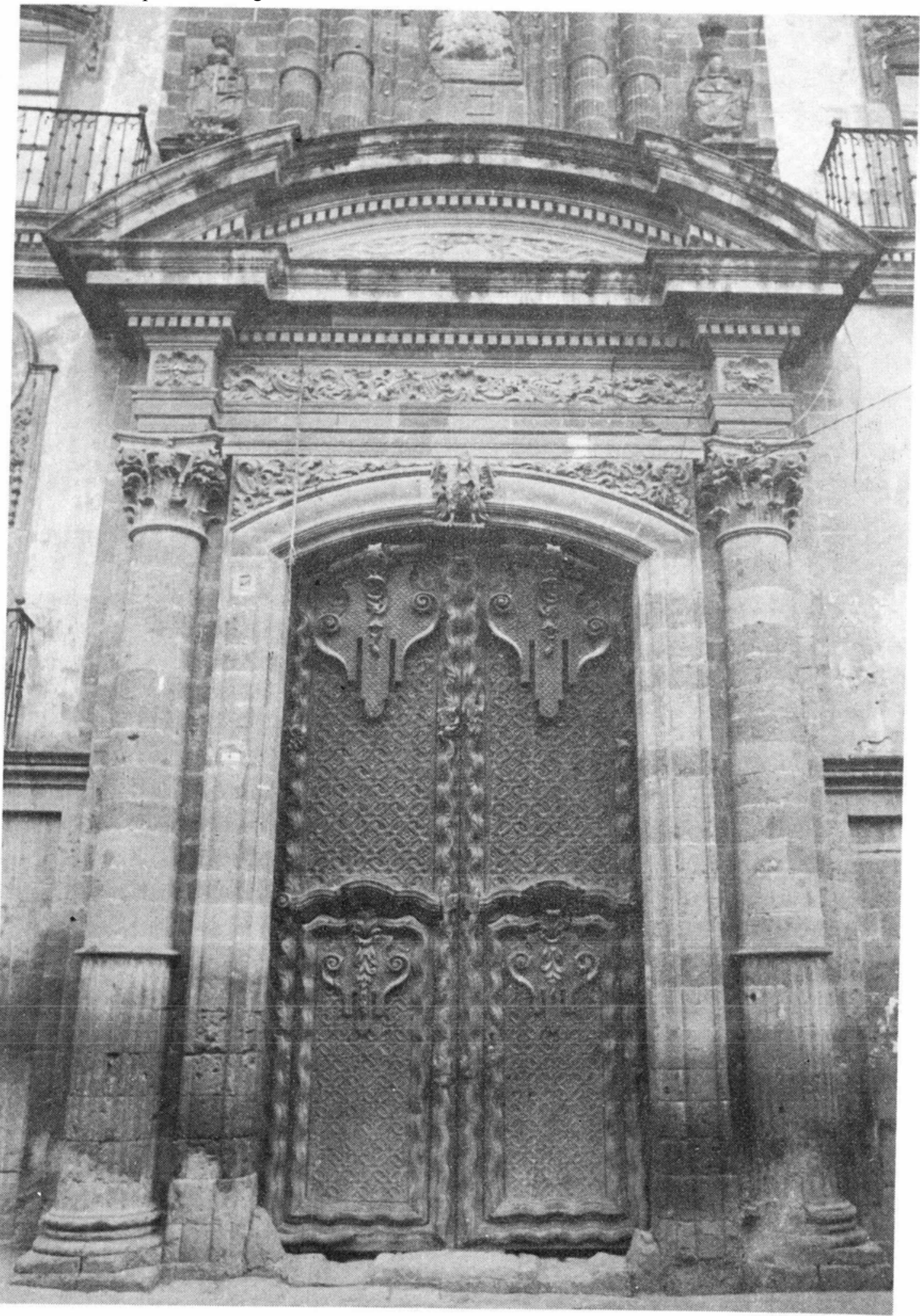

16. San Miguel Allende, Gto. Palacio de los Condes de la Canal. Siglo XVIII. 